\title{
Meble z biografią. Minimalizm, recykling i nostalgia we współczesnych praktykach zamieszkiwania
}

\author{
Furniture with biographies: \\ Minimalism, recycling and nostalgia \\ in contemporary practices of dwelling
}

DOI: $10.12775 /$ LL.3.2021.006 | CC BY-ND 4.0

\begin{abstract}
The paper presents a reflection on relations between people and material objects based on the results of ethnographic research on practices of dwelling within the space of Polish cities. The main subject of the analyses undertaken by the author are the ways in which furniture dating to the period of The Polish People's Republic (PRL) functions in contemporary residential interiors, as objects with a rich cultural biography, which actively participate in contemporary practices of dwelling and play an important role in building the sense of identity of their current owners and users. The author perceives links between a nostalgic return to artefacts from the period of PRL and current social problems and challenges, mainly the overproduction of things and the need to halt climate change. Nostalgia in these considerations is understood as a kind of defence mechanism against the accelerated rhythm of changes occurring in the world, including climate and environmental changes; it is also an expression of the contestation of thinking about human life solely through the prism of purely economic categories.
\end{abstract}

KEYWORDS: practices of dwelling, item biographies, minimalism, nostalgia, socialism 
Antropologiczne podejście do świata przedmiotów zakłada, że człowiek wchodzić może w złożone wzajemne relacje z obiektami materialnymi, które posiadają nie tylko wymierne właściwości fizyczne i użyteczność formalną, ale także - jako artefakty fizyczne - naznaczone zostały zróżnicowanym i zmiennym doświadczeniem biograficznym, osadzonym w określonych kontekstach społeczno-kulturowych (por. Kopytoff 2003; Krajewski 2008). Wyroby materialne noszą zatem zazwyczaj, zarówno w swej formie, jak i w strategiach użytkowania, ślady złożonych i wielotorowych sposobów uczestnictwa w życiu społecznym w szerokiej perspektywie czasowej. Tym samym stanowić mogą impuls do przywoływania rozmaitych narracji o przeszłości, wywoływania wspomnień oraz emocji związanych z czasem minionym, a jednocześnie przenoszenia dawnych znaczeń w kontekst teraźniejszości. Przedmioty z tak rozumianą biografią funkcjonują częstokroć we współczesnym świecie jako nośniki nostalgicznego powrotu do przeszłości, ale także obiekty materialne wpisujące się wraz ze swym kulturowym doświadczeniem w nowe potrzeby i cele ludzkiego działania. Do artefaktów o tak rozumianym statusie należeć mogą meble, pochodzące z okresu PRL-u, które, co potwierdziły wyniki przeprowadzonych przeze mnie badań jakościowych, aktywnie uczestniczą we współczesnych praktykach zamieszkiwania.

Podstawowym celem prowadzonych przeze mnie badań etnograficznych było szczegółowe rozpoznanie aktualnych sposobów aranżowania i użytkowania przestrzeni mieszkań miejskich w polskich warunkach społeczno-kulturowych oraz ukazanie związków, jakie zachodzą pomiędzy ludźmi i przedmiotami w kontekście codziennych praktyk zamieszkiwania. Wyniki badań pokazały m.in., że jedną z istotnych grup przedmiotów użytkowanych obecnie we wnętrzach domowych stanowią produkty polskiego przemysłu meblarskiego, pochodzące głównie $\mathrm{z}$ lat 50. i 60. XX w., które opisywane były przez rozmówców jako rzeczy darzone szczególną atencją. Co ważne, ich aktualni użytkownicy wykazywali nie tylko zadowolenie z posiadania tego typu wyrobów, ale także pewną wiedzę o ich projektowej genezie i kulturowym pochodzeniu. Wiele z tych mebli, jak zauważali sami uczestnicy badań, określić można dziś mianem rozpoznawalnych ikon polskiego wzornictwa $\mathrm{z}$ okresu powojennej nowoczesności, że wymienię chociażby fotel Chierowskiego ${ }^{1}$, który funkcjonuje obecnie jako jedno z najbardziej rozpoznawalnych osiągnięć powojennego polskiego designu o ponadczasowej formie, stolik kawowy (patyczak) ${ }^{2}$, produkowany od lat 6o. w Obornickiej Fabryce Mebli w Obornikach Wielkopolskich czy pojemne podłużne komody, z przesuwnymi drzwiami i szufladami, zwane potocznie jam-

1 Fotel 366 został zaprojektowany przez Józefa Chierowskiego (1927-2007) w 1962 r. na potrzeby Dolnośląskiej Fabryki Mebli w Świebodzicach. Miał on prostą i lekką konstrukcje, cechował się nowoczesnym i minimalistycznym wyglądem. Jego produkcję kontynuowano nieprzerwanie do lat 8o. XX w. (Minerwa 2018).

2 Stolik typu patyczak (366) to również projekt autorstwa Józefa Chierowskiego. Wyróżniał się lekką formą, w której cienki laminowany blat wsparty był na charakterystycznych smukłych i zwężających się ku dołowi podporach. 
nikami³ ${ }^{3}$ które wytwarzano między innymi w Zielonogórskiej Fabryce Mebli. Wyroby tego typu były obecne we wnętrzach mieszkalnych moich rozmówców jako obiekty atrakcyjne pod względem formy, naznaczone bogatą kulturowa biografią, które zostały przez nich ocalone przed zniszczeniem i wcielone niejako na nowo w kontekst ich domowych aktywności. Wskazane przedmioty częstokroć umożliwiały też ich właścicielom zachowanie pamięci o rodzimej, czasem też rodzinnej przeszłości, ale przede wszystkim traktowane były jako istotny element ich aktualnych praktyk tożsamościowych.

W swoich rozważaniach chciałabym przyjrzeć się sposobom funkcjonowania mebli pochodzących z okresu PRL-u we współczesnych wnętrzach mieszkalnych, zwrócić uwage na ich bogatą kulturową biografię, aktualną użyteczność oraz rolę w budowaniu poczucia tożsamości ich obecnych właścicieli i użytkowników. Zamierzam także rozważyć ich status jako aktywnych zabytków peerelowskiej kultury materialnej, o walorach zarazem artystycznych, jak i użytkowych. Określenie „aktywne zabytki” odnoszę do przedmiotów mocno związanych z kulturową przeszłością, wywołujących emocje i poczucie nostalgicznego powrotu do czasów minionych, a jednocześnie podlegających zmianom i otwartych na nowe funkcjonalności, umożliwiające wchodzenie $\mathrm{z}$ nimi w interakcje nie tylko okazjonalnie, w sytuacji zazwyczaj dosyć statycznej muzealnej ekspozycji, ale w sposób bardziej intensywny, permanentny, przy okazji codziennych działań. Warto w tym miejscu podkreślić, że wnętrze domowe w kulturze współczesnej w sposób szczególny stanowi manifestację przyjmowanego przez mieszkańców stylu życia, jest przestrzenią podlegającą zabiegom projektowej personalizacji, a umieszczane w nim przedmioty materialne funkcjonują jako ważne wsporniki tożsamościowe i pośredniczą w złożonych procesach komunikacji z innymi (por. Woroniecka 2007: 17).

Swoje rozważania opieram na wynikach badań etnograficznych, które przeprowadziłam w latach 2019-2021 wśród mieszkańców budownictwa wielorodzinnego w dużych polskich miastach ${ }^{4}$, głównie w Łodzi, ale także w Warszawie, Wrocławiu i miastach aglomeracji śląskiej, pytając ich o szczegółowe aranżacje zamieszkiwanych przestrzeni domowych i sposoby ich codziennego użytkowania. Pierwszy etap tych badań, prowadzonych zgodnie z założeniami antropologii designu, dotyczył wyłącznie przestrzeni głównego pomieszczenia mieszkalnego i jego wyposażenia (nosił tytuł Przestrzeń zamieszkiwana - pokój dzienny), drugi

3 Komody zwane potocznie jamnikami występowały w różnych wzorach, a zalicza się do nich między innymi komodę o nazwie Violetta, produkowaną w Zielonogórskiej Fabryce Mebli czy komodę typu 1050/B wyrabianą w fabryce w Bytomiu (cotozafotel b.d.).

$4 \mathrm{~W}$ przeprowadzonych badaniach skupiłam się na przestrzeniach mieszkań miejskich w budownictwie wielorodzinnym, co pozwoliło na zachowanie względnej jednorodności w zakresie metrażu zamieszkiwanych przestrzeni i rodzaju użytkowanych w nich pomieszczeń, które różniły się znacznie w stosunku do przestrzeni domów jednorodzinnych, o większej powierzchni użytkowej, zlokalizowanych najczęściej poza miastem. Wybierani rozmówcy musieli także zamieszkiwać dane mieszkanie w sposób stały (dłużej niż dwa lata) i mieć realny wpływ na jego aranżacje (nie interesowały mnie osoby wynajmujące krótkoterminowo przestrzenie przygotowane w całości przez ich formalnych właścicieli). 
etap zaś obejmował już rozmowy o całym zamieszkiwanym wnętrzu domowym i szczegółowych sposobach jego użytkowania, z naciskiem na przekaz informacji o potrzebach i praktykach służących komfortowi zamieszkiwania (Przestrzeń zamieszkiwana - codzienność i praktyki „dobrego życia”). Uczestnikami badań były osoby w wieku 22-68 lat; w zdecydowanej większości były to kobiety, które same decydowały o aranżacji i sposobie funkcjonowania w zamieszkiwanej przez siebie (i bliskich) przestrzeni. Poprzez zastosowanie techniki pogłębionego wywiadu swobodnego chciałam dotrzeć do indywidualnych doświadczeń rozmówców i pozyskać rozbudowane wypowiedzi, pokazujące subiektywność ich doznań związanych z aranżacją i użytkowaniem przestrzeni domowej, ich codzienne praktyki i szczegółowe przemyślenia dotyczące wybranych fragmentów wnętrza oraz występujących w tym wnętrzu przedmiotów. W sumie w dwóch etapach badań etnograficznych udało mi się przeprowadzić 34 bardzo obszerne i pogłębione rozmowy.

Spotykane w przestrzeniach domowych osób badanych meble z okresu PRL-u to głównie przedmioty produkowane w Polsce w latach 1956-1968, czyli w okresie, który po czasie realnego socjalizmu, na skutek wyraźnych wpływów kultury Zachodu, określony został mianem nowoczesnego (Wybieralski 2007: 23). Nowoczesność projektowanych i wytwarzanych wówczas mebli, jak zauważa Karolina Bittner, wyrażać miała się w formie, kolorze, wzorze i surowcu (2017: 238-239). Polegała ona również na dopasowywaniu się tych obiektów do niedużych (około 30-40 $\mathrm{m}^{2}$ ) metraży polskich mieszkań miejskich, które najczęściej ograniczały się do dwóch pokoi i małej kuchnis. Pojawiła się zatem potrzeba wytwarzania mebli o niewielkich rozmiarach i dużej funkcjonalności. Nowe meble miały być też atrakcyjne pod względem wizualnym, co wyrażał między innymi program działania Instytutu Wzornictwa Przemysłowego, syntetycznie ujęty w haśle: „Piękno na co dzień i dla wszystkich” (Przedpełski 1987: 59). Program ten, opracowany przez Wandę Telakowską, akcentował ideę racjonalnego projektowania - zakładał zaspokajanie potrzeb estetycznych, dostosowywanie do nowych warunków mieszkaniowych i dostępność produktów projektowych dla szerokich kręgów społeczeństwa. Warto dodać, że działalność samego Instytutu koncentrowała się na projektowaniu wnętrz mieszkalnych i ich wyposażenia, a prace koncepcyjne wspierane były działalnością badawczą (Przedpełski 1987: 61-62). Instytut, uczestnicząc w realizacji programów rządowych, miał więc realny wpływ na podnoszenie jakości użytkowej polskich przestrzeni domowych.

$\mathrm{W}$ rodzimej produkcji meblarskiej z lat 50. i 60. XX w. pojawiła się zatem potrzeba nowej estetyki, a wraz z nią wprowadzone zostały nowe lekkie formy, większa różnorodność kolorystyczna i niewykorzystywane dotąd materiały, takie jak sklejka, wzorzyste tkaniny oraz tworzywa sztuczne. Nowoczesne meble miały być nie tylko funkcjonalne, ale także tanie i łatwe w produkcji przemysłowej.

5 O szczegółach dotyczących polityki mieszkaniowej państwa polskiego w okresie powojennym pisze Dariusz Jarosz (2010: 27-45). 
W tym miejscu warto tylko przypomnieć, że w latach powojennych te ambitne propozycje meblarskie nie były jednak łatwo dostepne na rynku, nie trafiały bezpośrednio do sklepów, a w polskich gospodarstwach domowych nie myślano wówczas wyłącznie o kupowaniu mebli; wciąż istotne były ważniejsze problemy społeczne i gospodarcze. Lata powojenne dla większości polskiego społeczeństwa wiązały się z konsekwencjami masowych migracji ludności ze wsi do miast, ale także $\mathrm{z}$ powolnym wychodzeniem $\mathrm{z}$ degradacji materialnej i społecznej: pokłosiem wywłaszczenia z majątków, koniecznością przystosowania się do niskiego poziomu życia i trudnych warunków bytowych (Cobel-Tokarska 2014: 25). Nie znaczy to, że projektowane wówczas przedmioty nie cieszyły się uznaniem w środowiskach artystycznych, ale sukces na tym polu nie do końca przekładał się na natychmiastową intensyfikacje procesu produkcji i sprzedaży nowoczesnych mebli. $\mathrm{Z}$ czasem trafiały one jednak pod dachy polskich domostw.

Mówiąc o projektach mebli z okresu nowoczesności, warto również podkreślić, że zainteresowanie osiąnnięciami polskiego powojennego designu w niedawnej przeszłości wykazywały już placówki muzealne, jako instytucje statutowo zobowiązane do ochrony i ekspozycji zabytków kultury o wartości historycznej i artystycznej. Pierwsza wystawa poświęcona sztuce użytkowej PRL-u została zaprezentowana w Muzeum Rzemiosł Artystycznych, Oddziale Muzeum Narodowego w Poznaniu w 1991 r. Dotyczyła projektów mebli, odbiegających nieco swym poziomem artystycznym od specyfiki powojennej polskiej rzeczywistości, datowanych na lata 50. XX w., co wyrażał już sam jej tytuł - Użytkowa fantastyka lat pięćdziesiątych. Następnie, po kilkuletniej przerwie, została przygotowana wystawa Rzeczy pospolite w Muzeum Narodowym w Warszawie w 2000 r., która zainicjowała zainteresowanie designem PRL-u w szerszych kręgach społeczeństwa. W 2007 r. Instytut Wzornictwa Przemysłowego zorganizował wystawe zatytułowaną Wiecznie Młode. Polski vintage, natomiast w roku 2011 ogromnym zainteresowaniem cieszyła się wystawa Chcemy być nowocześni. Polski design 1955-1968, przygotowana na podstawie kolekcji Muzeum Narodowego w Warszawie (Bittner 2017: 242-243).

Traktowanie wzornictwa okresu PRL-u w kategoriach artystycznych jako wybitnych osiągnięć sztuki projektowania z lat 50. i 6o. XX w. oraz zabytków sygnowanych nazwiskami swych twórców jest już więc obecnie dość powszechnym podejściem eksperckim. Włączanie ich jednak powtórnie w przestrzeń użytkową polskich mieszkań, ze względu na oryginalny kształt formalny, wywołujący określone skojarzenia oraz poczucie nostalgii i sentymentu wobec niedalekiej przeszłości, to już nieco inna kwestia. Choć paradoksalnie obecni użytkownicy mebli z PRL-u również starają się nabywać kompetencje eksperckie i wchodząc w posiadanie tego typu artefaktów zaczynają pogłębiać swoją wiedzę na temat polskiego powojennego wzornictwa, a wiedza ta w ich doświadczeniu łączy się częstokroć ze wspominaniem przeszłości własnej rodziny. Biografia kulturowa omawianych przeze mnie przedmiotów, a właściwie jej początkowy etap, zakłada zatem związki z historią polskiego projektowania i produkcji meblarskiej, ale także uwikłanie w kontekst życia społecznego (w tym 
prywatnego) w okresie PRL-u oraz szczegółowych doświadczeń i praktyk wielu polskich grup domowych. Dostrzeżenie zaś tego etapu w kulturowej biografii przedmiotów ma swoje konsekwencje w sposobach wartościowania poszczególnych mebli przez obecnych użytkowników i określania społecznego statusu tych przedmiotów.

Analizując wyniki przeprowadzonych badań zauważyć można, że meble z czasów PRL-u spotykane we wnętrzach domowych osób badanych trafiały w ich ręce zazwyczaj po okresie społecznego zawieszenia i biograficznego niebytu, jako rzeczy wyciągane ze śmietników czy innych miejsc służących przechowywaniu przedmiotów niepotrzebnych i tym samym zostały ocalone przed całkowitym zapomnieniem. Nosiły na sobie liczne ślady wcześniejszych doświadczeń i sposobów funkcjonowania, wymagały czasem drobnych napraw czy odświeżenia. Jednocześnie dawna, oryginalna forma materialna i pewna niedoskonałość fizyczna stanowiła ich najważniejszy atut. W założeniu użytkowników nie warto było ich szczególnie udoskonalać, by ocalić w danej rzeczy to, co było w niej najcenniejsze, czyli autentyczność, oryginalny i nienaruszony kształt, a nawet lekką ułomność, wpisaną z reguły w obiekty materialne poddawane upływowi czasu. Zachowanie oryginalnej formy decydowało o wartości tych mebli, które traktowane były przez obecnych właścicieli ze zdecydowanie większym szacunkiem niż meble dostępne w aktualnej ofercie rynkowej.

Rozmówcy przedstawiali w swoich wypowiedziach osobiste i subiektywne motywacje, które leżały u podstaw ich zainteresowania meblami z okresu powojennej nowoczesności. Mówili o źródłach ich pozyskiwania i swoich indywidualnych odczuciach wobec tych przedmiotów, naznaczonych bogatą kulturową biografią. W celu zilustrowania i wzbogacenia moich spostrzeżeń przytoczę kilka fragmentów zebranych wypowiedzi:

Po prostu lubię te rzeczy [...]. Do mnie rzeczy przemawiają i wiem, które mam wziąć, a które nie. Mówią: „Weź mnie”. [...] Moje przedmioty muszą być solidne, wykonane ze starannością, a nie masowo, dlatego wybieram stare rzeczy, bo kiedyś troszeczkę inaczej ta produkcja się odbywała, nie produkowano tak jak Ikea na cały świat, tylko pokrywano mniejsze obszary. Są to solidniejsze rzeczy i trwalsze, i ładniejsze, klasyczne (kobieta, 25 lat, Łódź).

Nie przejdę obok śmietnika obojętnie. Nie chciałabym być źle zrozumiana, że jestem kloszardem jakimś, który gdzieś grzebie. Ale też jak widzę u kogoś coś, co miałby wyrzucić, a jest to dziedzictwo ewidentnie warte zapamiętania i zbierania..., to nie mogę zrezygnować (kobieta, 61 lat, Łódź).

O, zapomniałam przecież o jednym ważnym meblu w pokoju głównym! [krzyczy] Między kwietnikiem a tym, pomocnikiem, stoi taki... gazetownik z lampą. I też on został znaleziony pod blokiem! Ktoś takie piękne coś wyrzucił (kobieta, 22 lata, Łódź). 
Lubię szukać rzeczy. Nawet nie tyle że szukać tych rzeczy, chociaż to też lubię, ale znajdować je. Na przykład jak stoi coś pod śmietnikiem, czego się nie spodziewałam, albo w pracy, gdzie pracuję, no jeszcze nie wyszedł PRL tak naprawdę, więc jest dużo przedmiotów. Jak te rzeczy mnie same zaskakują i same na mnie wpadają albo ja wpadam na nie w sumie, że nie oczekuję, że coś znajdę, a tu nagle wazon jakiś albo jakaś filiżanka, albo jakiś inny fotel czy krzesło. [...] Są to zazwyczaj rzeczy, to znaczy wszystkie te rzeczy są przekazane do kasacji i gdzieś się turlają po kątach i wszyscy się w sumie cieszą, że ja zabieram te rzeczy, no bo wszystko trwa, wszystko kosztuje, a jak je zabieram to i więcej pieniędzy można zaoszczędzić i większy porządek mają (kobieta, 33 lata, Łódź).

Lubię stół też, który tam mam, taki lakierowany peerelowski. Fajniejszy niż to biurko tutaj, takie z Ikei białe. [...] Z Adamem kiedyś pojechałam po niego, bo zamówiłam go na Olx-ie, on był za 50 złotych czy za jakieś takie małe pieniądze. W każdym razie $\mathrm{z}$ moim kolegą Adamem, jeszcze mieszkając w poprzednim mieszkaniu, pojechałam po ten stół i znosiliśmy go razem po jakichś takich kręconych schodkach w kamienicy, a potem jechaliśmy z nim autobusem i było strasznie śmiesznie. [...] Szafa też taka lakierowana, PRL-owska, z Olx-a. Za darmo w ogóle ona była. Tylko musiałam zorganizować przywiezienie jej. Już nie autobusem, no bo jednak to trochę za duża, żeby ją przewieźć autobusem. Musiałam wynając transport. Ale to jest super, to jest super fajna szafa (kobieta, 29 lat, Łódź).

Głównie to są takie rzeczy pozbierane od rodziny albo znajomych. No jak znajdujemy coś u nas przy śmietniku, to strasznie chcemy to wszystko brać, bo tam często piękne stare meble wyrzucają, ale trochę sie jeszcze boimy tych tapicerowanych, bo to trudno wyprać [...]. W zasadzie to staramy się nie kupować mebli, ostatnio tylko kupiliśmy jakiśs regał w Ikei, ale to tylko dlatego, że mieliśmy tylko jakichś 71 centymetrów do wypełnienia i chcieliśmy taką właśnie szerokość znaleźć; nawet w Ikei trudno było go znaleźć. Ale zazwyczaj po prostu bierzemy meble po kimś, od kogoś (kobieta, 24 lata, Łódź).

W zebranych podczas badań wypowiedziach peerelowskie meble występowały czasem także jako przedmioty odziedziczone po bliskim lub dalszym członku rodziny lub z takimi były kojarzone. Zyskiwały w ten sposób dodatkowo status rodzinnej pamiątki, przywoływały na myśl konkretne osoby, ich wnętrza mieszkalne, czasem także ich codzienne lub odświętne praktyki, które kumulowały się wokół przedmiotów podobnych w formie do obecnie posiadanych lub z nimi tożsamych. Obecność tych mebli w domach rozmówców świadczyła też o tym, że ważne jest, by zamieszkiwać wnętrza wypełnione nie tylko dobrą formą, ale także wywoływaną przez tę formę wspomnieniową opowieścią o przeszłości, 
o czasach i doświadczeniach pozytywnie wartościowanych, do których lubimy wracać z sentymentem. Omawiane artefakty wpisywały się zatem w nostalgiczne praktyki tożsamościowe swych użytkowników, polegające na wyrażaniu tęsknoty i poszukiwaniu wsparcia w metaforycznym domu, który już nie istnieje albo nigdy nie istniał. Praktyki te zakładają tym samym grę z wyobraźnią oraz nakładanie się na siebie przeszłości i teraźniejszości (Boym 2002: 273).

Przeprowadzone badania pokazały, że interesujące nas „meble z biografią” w sposób naturalny uwikłane były w rozmaite praktyki życia codziennego swych obecnych właścicieli, wchodziły w płynne relacje zarówno z innymi domowymi przedmiotami, jak i z użytkującymi je ludźmi, dla których stanowiły ważne elementy wyposażenia domu. Rozmówcy zwracali uwage na niepowtarzalną i ponadczasową stylistykę tych mebli, naturalne materiały, z których zostały one wykonane i możliwość interesującego zestawiania ich z innymi elementami wyposażenia wnętrz, doceniali także ich ponadczasową funkcjonalność:

Moje mieszkanie jest niewielkich rozmiarów i przestrzenią dla mojego hobby jest wcześniej wspomniana ława „komuno-coco” [śmiech]. To na niej rozkładam farby, pędzle i przedmioty, które akurat ozdabiam (kobieta, 44 lata, Łódź).

W ogóle wszędzie w pokoju jest dużo kwiatów. Kwiaty w dużej mierze są również ze śmietników albo z drugiej ręki. Wzięte od kogoś z Olx-a, przyniesione ode mnie z pracy. Po prawej jest stara kozetka. Jest to rozkładana fotelosofa. Też z okresu komuny. Jest następnie po prawej stronie komoda, tak zwany patyczak. Na patyczaku stoi 55 -calowy telewizor. Trochę odstaje od wszystkiego, ponieważ na tej komodzie, tak zwanej RTV-ce nawet stoi sprzęt - radio ze wzmacniaczem, z kolumnami, które również są z okresu PRL-u. Na wprost drzwi wisi na ścianie reprodukcja obrazu Beksińskiego. [...] Pod obrazem stoi kolejna komoda, która ma w środku, jak gdyby wystawki, witrynki, szybę. Tam stoją płyty, jakieś inne różne durnostojstwa. Później jest..., później idąc, znajduje się szafka, która jest tak naprawdę maszyną. Na szafce stoi wazon Asteroid i dwa inne wazony. Jeden jest z, z... zaraz sobie przypomnę, z Łysej Góry, drugi jest również z Bolesławca. Przed maszyną jest stary fotel. Modelu nie pamiętam. Później podam. Wszyscy go na pewno znają, bardzo go lubię (kobieta, 33 lata, Łódź).

W tym miejscu warto zauważyć, że współczesne praktyki tożsamościowe częstokroć polegają na sięganiu do zasobów własnej kulturowej przeszłości, wynajdywaniu drobnych, mających naturę szczegółu, przedmiotów materialnych, które stają się istotnymi wspornikami naszego bycia w świecie i dają jednostce poczucie ontologicznego bezpieczeństwa (por. Giddens 2001; Krajewski 2008). Przeszłość kulturowa przywoływana przez omawiane meble to czas, który w polskiej historii utrwalił się jako okres mocno naznaczony doświadczeniem 
niedoboru, braku w różnych sferach życia społecznego, także w obszarze kultury materialnej życia rodzinnego. To także czas wyczekiwania na upragnione meble - tapczany, fotele, później meblościanki, sprzęty gospodarstwa domowego, telewizory, które po nabyciu darzone były zwykle dużym szacunkiem i troską użytkowników. Obserwowany obecnie powrót do wybranych artefaktów pochodzących z tego okresu wydaje się w tym kontekście nieprzypadkowy. W moim przekonaniu, tego rodzaju praktyki traktować można jako wyraz zmęczenia nadprodukcją i super intensywną konsumpcją wciąż nowych, oferowanych przez rynek dóbr. Te zachowania stanowić mogą szczególnego rodzaju aprobatę minimalizmu, zakładającego też przecież, szczególnie w polskim wydaniu, wielokrotne, wtórne wykorzystywanie rzeczy już posiadanych, które wciąż zachowują swą użytkową wartość (por. Woźniak 2015), a w wypadku omawianych przeze mnie mebli także wartość artystyczną, jako zabytki polskiego designu. Tak postrzegany minimalizm, który nie musi przecież zawsze polegać na kompulsywnym pozbywaniu się nadmiaru rzeczy już posiadanych, oznacza większy szacunek dla dóbr mocno wpisanych w nasze kulturowe i biograficzne doświadczenia. Może być traktowany jako wyraz nurtu no waste $\mathrm{w}$ polskim wydaniu, a dotyczy pokolenia ludzi, którzy pamiętają PRL często jedynie z rodzinnych opowieści, ale w tym okresie upatrują swoich kulturowych korzeni. W swej postawie życiowej nie tylko chcą się przyznawać do tego rodzaju związków z czasami powojennego polskiego komunizmu, ale także zależy im, aby te związki bardzo wyraźnie manifestować, przedkładając jednocześnie to, co lokalne, ponad to, co stanowi produkt o charakterze globalnym. Jak wynika z przeprowadzonych badań, przyjmowanie takiej postawy społecznej faktycznie przyczynia się do ratowania wielu unikatowych przedmiotów z okresu PRL-u i nadawania im funkcji aktywnych zabytków.

Warto w tym miejscu dodać, że czas powojennego niedostatku sprzyjał również intensywnemu wykorzystywaniu własnych umiejętności rękodzielniczych (wspomnieć można tu o własnoręcznym szyciu ubrań, cerowaniu pończoch, przygotowywaniu przetworów na zimę), to czas naprawiania, a nie wyrzucania tego, co zostało uszkodzone, oraz ograniczonego produkowania śmieci. Sytuację tę wymuszały oczywiście trudne warunki bytowe w większości polskich gospodarstw domowych oraz powszechne społeczne uznanie dla zdobywania dóbr trudno dostępnych na rynku, ale sentyment do tego rodzaju praktyk z dużą siłą odradza się we współczesnych zachowaniach wielu młodych Polaków, którzy traktują takie działania jako sprawdzony kulturowy kapitał. Uczestnicy badań wspominali również o tym, że w miare posiadanych możliwości i umiejętności, poddawali omawiane meble rękodzielniczym zabiegom renowacyjnym, dzięki czemu czasem zyskiwały one zupełnie nowe oblicze i bardziej niepowtarzalny charakter:

Pomiędzy oknami jest komoda i to jest komoda po mojej babci, którą odnowiła moja mama. Moja mama ją odnowiła, bo ona lubi się takimi rzeczami zajmować. Starliśmy starą warstwę papierem ściernym i pomalowaliśmy na biało (mężczyzna, 22 lata, Łódź). 
Niedawno do tego pokoju został wstawiony jeszcze nowy mebel. To jest taki niski stolik, który został postawiony przy kanapie i myślę, że jest bardzo potrzebny. Zobaczyłam go oczami wyobraźni, że mógłby stanąć w tym pokoju, a stał jako bardzo zaniedbany mebel, zniszczony, w miejscu, w którym pracuję, na korytarzu. Okazał się nikomu niepotrzebny i zbyteczny i mogłam go zabrać. Poprosiłam znajomego stolarza, żeby go według mojego pomysłu trochę zreanimował, zmienił mu kolor, no i to się stało i jestem z niego bardzo zadowolona (kobieta, 55 lat, Łódź).

Wyniki przeprowadzonych przeze mnie badań pozwalają przypuszczać, że powrót do mebli z epoki PRL-u łączy się dziś również ze zjawiskiem recyklingu i powtórnym wykorzystywaniem tego, co nie pachnie już nowością i wymaga wkładu pracy rąk własnych, a co za tym idzie, także ze społecznymi ruchami proekologicznymi i zabiegami o powstrzymanie niepożądanych zmian klimatu. W moim przekonaniu to właśnie zagrożenia, których jesteśmy obecnie coraz bardziej świadomi ze względu na postępującą degradację środowiska, powodują, że stajemy się bardziej odporni na uleganie rynkowym ofertom i nieustanne, bezrefleksyjne konsumowanie nowych dóbr. Jednocześnie przedmioty materialne wciąż aktywnie uczestniczą w życiu społecznym, a nawiązywane $\mathrm{z}$ nimi relacje służą budowaniu poczucia jednostkowej i grupowej tożsamości oraz kształtowaniu związanego z nią sposobu bycia. W tej sytuacji odpowiedzią na potrzebę powstrzymania zmian klimatu, przy jednoczesnym dążeniu do określania przez przedmioty własnej tożsamości może być dla niektórych właśnie minimalizm, polegający nie tylko na ograniczeniu ilości używanych rzeczy, ale także na ocalaniu, pozyskiwaniu i ponownym wykorzystywaniu wyrobów nietuzinkowych, ponadprzeciętnych, wyjątkowych. Potrzebę tak rozumianego minimalizmu, który powinien oznaczać ograniczenie systemu nowej produkcji i wyjście ku ekologii podkreśla choćby Bruno Latour w jednym ze swoich ostatnich esejów, rekomendując konieczność wyciągnięcia wniosków z doświadczenia pandemii, która w ciągu kilku tygodni doprowadziła do zawieszenia światowego systemu gospodarczego i pokazała, jak niewiele nam tak naprawdę potrzeba do spokojnego i odpowiedzialnego życia (Latour 2020).

$\mathrm{W}$ takim świetle interesujące mnie w tych rozważaniach meble $\mathrm{z}$ okresu PRL-u, jako przedmioty dobrze zaprojektowane i w tym sensie ponadczasowe, mogą niejako na nowo ujawniać swą wartość oraz znaczenia, w sposób dość różnorodny i nie do końca przewidywalny. Odzyskiwane z przestrzeni społecznego niebytu nie pełnią już tylko roli ocalonych skarbów, przedmiotów z przeszłością i z przeszłości, ale zyskując drugie/kolejne/nowe życie, rekonstruują swój potencjał i otwierają się na nowe możliwości, stają się znów interesujące i potrzebne. W przestrzeniach domowych swych właścicieli, wchodzą w relacje z całym zestawem innych artefaktów wypełniających wnętrza, prowokując także do kreatywnych i nowatorskich, często eklektycznych, rozwiązań aranżacyjnych. Znajdując się we właściwym dla nich kontekście przestrzennym, zachęcają, by wchodzić z nimi w rozmaite relacje, otaczać je opieką, twórczo wykorzysty- 
wać; kumulują wspomnienia, ucieleśniają wartości, wywołują nowe odczucia estetyczne i odzwierciedlają aktualne potrzeby. Odgrywają więc w życiu społecznym intrygującą rolę aktywnych zabytków, które przywracając pamięć o przeszłości, jako przedmioty materialne wydają się być w nieustannym ruchu i nie pozostają jedynie w roli statycznych eksponatów. Taki status omawianych mebli bardzo mocno podkreśla ich materialność i wpisuje się w koncepcję Tima Ingolda (2018) dotyczącą nieustannego współwytwarzania się świata materialnego; świata artefaktów, który ze względu na swoje substancjalne właściwości podlega nieustannym zmianom i przekształceniom, nie będąc nigdy projektem skończonym. Taka też jest natura omawianych przeze mnie mebli, mocno zanurzonych w przeszłości, ale też otwartych na zupełnie nowe możliwości i prowadzących dialog z przyszłością. I właśnie w tym ruchu naprzód, jak pisze Ingold (2018: 135), trzeba szukać twórczego potencjału każdego materialnego dzieła. Jak się zatem okazuje, formy zamieszkiwania są silnie zależne nie tylko od tradycji kulturowej, ale także od przemian zachodzących w życiu społecznym, uwzględniają pojawianie się nowych nurtów i idei, ale także trudnych wyzwań i problemów klimatycznych, gospodarczych i politycznych, które czasem warto rozwiązywać sieggając do tego, co znane i sprawdzone, do czego wracamy z nostalgią, ale też z zaufaniem.

Na koniec warto jeszcze dodać, że meble, dekoracje i sprzęty domowe pochodzące z okresu PRL-u cieszą się obecnie niezwykłą popularnością także w szerszej perspektywie życia społecznego. Są powszechnie wystawiane i sprzedawane na aukcjach internetowych prowadzonych na popularnych platformach handlowych i w serwisach ogłoszeniowych typu Allegro.pl, OLX.pl czy Sprzedajemy.pl, gdzie czasem osiągają wysokie ceny (głównie jako przedmioty odrestaurowywane, ale wiele zależy też od typu mebla), a zachwyt nad ich formą i praktyki intensywnej wymiany doświadczeń związanych z ich renowacją, stają się podstawą dla działania licznych grup na popularnych portalach społecznościowych (Facebook, Instagram, YouTube). Coraz więcej osób chce przedstawiać siebie jako miłośników i znawców mebli z tego okresu oraz zaangażowanych pasjonatów renowacji starych przedmiotów, przy okazji dzieląc się efektami swoich działań rekonstrukcyjnych oraz praktyk kolekcjonerskich. Za pośrednictwem tego typu grup środowiskowych nawiązywać można kontakty i wymieniać opinie $\mathrm{z}$ innymi ludźmi, którzy także doceniają wartość tego rodzaju przedmiotów, rozpoznają ich formy, mają świadomość ich kulturowej biografii i uczestniczą w sentymentalnych praktykach powrotu do PRL-u. W ten sposób interesujące nas meble biorą obecnie udział w swoistej społecznej grze znaczeń, budując platformę porozumienia i wymiany wiedzy pomiędzy ludźmi o podobnym kulturowym doświadczeniu oraz zbliżonych zainteresowaniach.

Co więcej, na fali nostalgii za wzornictwem z okresu PRL-u w ofercie rynkowej pojawiają się zupełnie nowe produkty, współczesne kopie oparte na rozwiązaniach projektowych znanych z przeszłości (z lat 50. i 6o. XX w.), które promowane są w nawiązaniu do rozpoznawalnego coraz powszechniej w świadomości społecznej nazewnictwa - fotel 366 Chierowskiego czy fotel Lisek 
(typu 300-190). W produktach tych odtwarzane są udane projektowo formy, a producenci marketingowo wykorzystują ich renomę i powszechną rozpoznawalność. Na pierwszy rzut oka efekty nowej produkcji trudno odróżnić od oryginałów, ale w swej materialnej i kulturowej istocie są one już czymś zupełnie innym niż meble produkowane w latach powojennych, które traktowane są częstokroć niczym „przedmioty z duszą”, noszące w swej formie ślady wcześniejszych relacji i więzi społecznych. Nostalgiczne praktyki w odniesieniu do materialnego i artystycznego dziedzictwa PRL-u ująć można zatem w szerszej perspektywie jako pragnienie powrotu do czasu pełnego prawdziwych emocji i autentyczności. Wypada więc zgodzić się z głosem Svetlany Boym, która stwierdza:

Postęp jakoś nie wyleczył nostalgii, lecz ją rozjątrzył. Podobnie globalizacja spowodowała, że zaczęto cenić więzi lokalne. Jako przeciwwaga do naszej fascynacji cyberprzestrzenią oraz wirtualną globalną wioską istnieje nie mniej globalna epidemia nostalgii, afektowana tęsknotą za społecznością z określoną zbiorową pamięcią, pragnieniem ciągłości we fragmentarycznym świecie. Nostalgia nieustannie odradza się jako system obronny w czasach przyspieszonego rytmu życia oraz historycznych wstrząsów (Boym 2002: 274).

Wnioski płynące z przeprowadzonych badań pozwalają przyznać, że nostalgia w kulturze współczesnej stała się swoistym mechanizmem obronnym przeciwko przyspieszonemu rytmowi zachodzących wokół zmian, w tym zmian klimatycznych i środowiskowych, oraz formą kontestacji takiego myślenia o ludzkim życiu, w którym postrzega się je wyłącznie przez pryzmat kategorii ekonomicznych. Jak się okazuje, praktyki sprzeciwu wobec ideologii nieustannego rozwoju światowego systemu gospodarczego mogą dokonywać się nie tylko na poziomie globalnym, ale także w obszarze lokalnych, jednostkowych decyzji i wyborów, które z czasem mogą się zjednoczyć i przekształcić w silniejszy grupowy manifest.

\section{BIBLIOGRAFIA}

Biskupska, K. (2014). Konsola była kiedyś stołem, czyli o wątkach przeszłości w mieszkaniu estetycznym. Społeczeństwo i Ekonomia, 2(2), 7-22.

Bittner, K. (2017). Chcemy znów być nowocześni. Kilka uwag o popularności peerelowskiego wzornictwa przemysłowego. W: A. Kisielewska, M. Kostaszuk-Romanowska, A. Kisielewski (red.), PRL-owskie re-sentymenty (s. 237-252). Gdańsk: Wydawnictwo Naukowe Katedra.

Boym, S. (2002). Nostalgia i postkomunistyczna pamięć (przeł. L. Stefanowska). W: F. Modrzejewski, M. Sznajderman (red.), Nostalgia. Eseje o tęsknocie za komunizmem (s. 270-301). Wołowiec: Wydawnictwo Czarne. 
Bryl-Roman, W. (2010). Polski vintage - odkrywanie peerelowskiego designu. W: M. Bogusławska, Z. Grębecka (red.), Popkomunizm. Doświadczanie komunizmu a kultura popularna (s. 51-6o). Kraków: Libron - Filip Lohner.

Burszta, W. (1997). Nostalgia i mit. W: E. Domańska (red.), Historia. O jeden świat za daleko (s. 119-130). Poznań: Instytut Historii Uniwersytetu Adama Mickiewicza.

Cobel-Tokarska, M. (2014). W jakiej Polsce żyliśmy? Historyczno-społeczne tło przemian obyczajowych w PRL-u. W: J. Zalewska, M. Cobel-Tokarska (red.), Od mody do obyczaju. Przemiany życia codziennego (s. 22-37). Warszawa: Wydawnictwo Akademii Pedagogiki Specjalnej.

cotozafotel (b.d.). Kredens typ 1050/B [post na blogu]. Pobrano z: https://cotozafotel.pl/kredens-typ-105o-b/

Czyńska, M. (2017). Dom polski. Meblościanka z pikasami. Wołowiec: Wydawnictwo Czarne.

Giddens, A. (2001). Nowoczesność $i$ tożsamość. „Ja” i społeczeństwo w epoce późnej nowoczesności (przeł. A. Szulżycka). Warszawa: Wydawnictwo Naukowe PWN.

Ingold, T. (2018). Splatać otwarty świat. Architektura, antropologia, design (przeł. E. Klekot, D. Wąsik). Kraków: Instytut Architektury.

Jarosz, D. (2010). Mieszkanie się należy... Studium z peerelowskich praktyk społecznych. Warszawa: Oficyna Wydawnicza ASPRA-JR.

Jasiołek, K. (2020). Astroid i pótkotapczan. O polskim wzornictwie powojennym. Warszawa: Wydawnictwo Marginesy.

Kopytoff, I. (2003). Kulturowa biografia rzeczy - utowarowienie jako proces (przeł. E. Klekot). W: M. Kempny, E. Nowicka (red.), Badanie kultury. Elementy teorii antropologicznej (s. 249-274). Warszawa: Wydawnictwo Naukowe PWN.

Krajewski, M. (2008). Ludzie i przedmioty - relacje i motywy przewodnie. W: J. Kowalewski, W. Piasek, M. Śliwa (red.), Rzeczy i ludzie. Humanistyka wobec materialności (s. 131-152). Olsztyn: Instytut Filozofii Uniwersytetu Warmińsko-Mazurskiego w Olsztynie.

Latour, B. (2020). Where to land after the pandemic? A paper and now a platform. Retrieved from: http://www.bruno-latour.fr/node/852.html

Minerwa (2018, 28 lipca). Ikony polskiego designu. Józef Chierowski i jego słynny fotel typ 366 [post na blogu]. Pobrano z: https://www.laminerva.pl/2018/o7/chierowski-fotel-typ-366.html

Przedpełski, A. (1987). Instytut Wzornictwa Przemysłowego, W: M. Kulik (red.), Wzornictwo w Polsce (s. 59-75). Warszawa: Instytut Wzornictwa Przemysłowego.

Puchała, M. (1964). Meble wspótczesne. Warszawa: Wydawnictwo Przemysłu Lekkiego i Spożywczego.

Woroniecka, G. (2007). Wstęp. Co znaczy mieszkać. W: G. Woroniecka (red.), Co znaczy mieszkać. Szkice antropologiczne (s. 13-27). Warszawa: Wydawnictwo TRIO.

Woźniak, A. (2015). Śmieci na wsi? Krótka historia wiejskiego gospodarowania rzeczami zbędnymi. W: K. Kulikowska, C. Olbracht-Prądzyński (red.), Śmieć w kulturze (s. 601-632). Gdańsk: Wydawnictwo Naukowe Katedra.

Wybieralski, W. (2007). Wzornictwo w Polsce do 1989 roku na tle politycznym i gospodarczym. Warszawa: Akademia Sztuk Pięknych, Wydział Wzornictwa Przemysłowego. 